\title{
Pembangunan Pariwisata Berkelanjutan Dalam Perspektif Sosial Ekonomi
}

\author{
Arief Setijawan \\ ${ }^{1}$ PWK Institut Teknologi Nasional Malang
}

\section{INFO ARTIKEL}

\section{Riwayat Artikel:}

Diterima: 08-11-2017

Disetujui: 18-12-2017

\section{Kata Kunci:}

Pariwisata

Berkelanjutan

Masyarakat

\section{ABSTRAK}

\begin{abstract}
Abstrak: Kegiatan kepariwisataan dapat menjadi solusi untuk mengeluarkan masyarakat dari jurang kemiskinan. Beberapa daerah kota/kabupaten telah berhasil menggunakan pariwisata untuk mengembangkan daerahnya. Namun pemanfaatan sumber daya pariwisata juga mesti selaras dengan pembangunan berkelanjutan diantaranya pariwisata berlandaskan budaya lokal dan pemberdayaan kelompok masyarakat. Penelitian ini merupakan penelitian kualitatif dengan pendekatan yang digunakan berdasarkan studi literature. Dari penelitian ini diperoleh kesimpulan bahwa pembangunan pariwisata berkelanjutan membutuhkan keterlibatan masyarakat secara menyeluruh dari keseluruhan tahapan pembangunan, dari tahap perencanaan hingga pelaksanaan pembangunan.
\end{abstract}

\begin{abstract}
Tourism activities can be a solution to get rid of society from poverty. Some regency have been successful in using tourism to develop their area. But the utilization of tourism resources must also be aligned with sustainable development including local culture-based tourism and community empowerment. This research is a qualitative research with approach which is used based on literature study. From this research, it can be concluded that sustainable tourism development requires comprehensive community involvement from all phases of development, from the planning stage to the implementation of development.
\end{abstract}

\section{A. LATAR BELAKANG}

Seluruh kegiatan pembangunan dalam perspektif pariwisata akan dapat dijadikan atau disinergikan dengan kegiatan pariwisata. Semisal sektor pertambangan jika dikemas dapat menjadi objek pariwisata atau bahkan kegiatan pembuatan kripik tempe pun jika dikemas juga dapat menjadi objek wisata. Karenanya pariwisata sebagai suatu sistem dapat disinergikan dengan kegiatan apapun termasuk kegiatan ekonomi kerakyatan bahkan dengan kehidupan sehari-hari di desa atau dusun yang paling terpincil sekalipun. Kondisi tersebut tentunya mendudukkan pariwisata menjadi salah satu jawaban untuk masalah kemiskinan.

Tujuan utama dari kegiatan pariwisata yang dilakukan adalah untuk memperoleh kesenangan atau menghilangkan perasaan tertekan karena rutinitas kerja. Pada kondisi ini perolehan kepuasaan dari kegiatan yang dilakukan wisatawan menjadi sangat penting. Konsep wisatawan berasal dari kata dalam bahasa Sansekerta, wisata yang berarti perjalanan yang sama atau dapat disamakan dengan kata travel dalam bahasa Inggris. Kata wisatawan dalam beberapa hal berbeda dengan tourist dalam bahasa Inggris (RG. Soekadijo,2000) [5]. Pariwisata menurut
Yoeti (2001;47) adalah kegiatan bersenang-senang. Syarat suatu perjalanan disebut sebagai perjalanan wisata, apabila (1) perjalanan di lakukan dari suatu tempat ke tempat lain, di luar tempat kediaman orang itu biasa tinggal; (2) perjalanan yang dilakukan minimal 24 jam atau lebih; (3) tujuan perjalanan semata-mata untuk bersenang-senang, dan tidak untuk mencari nafkah atau bekerja di tempat atau negara yang dikunjungi; dan (4) orang tersebut semata-mata sebagai konsumen di tempat yang dikunjunginya dan uang yang dibelanjakannya dibawah dari negara asalnya atau tempat tinggalnya semula dan bukan dicari atau diperoleh di tempat kota, atau negara yang dikunjunginya [6].

Pengeluaran wisatawan merupakan devisa di dalam meningkatkan kesejahteraan masyarakat dalam pengetasan kemiskinan. Pembangunan pariwisata dapat memberikan peluang bergeraknya berbagai kegiatan ekonomi masyarakat. Para turis yang berkunjung pada suatu negara membawa devisa ke negara tersebut. Dengan devisa, maka negara akan memperoleh dana pembangunan untuk meningkatkan perekonomian dan memberantas kemiskinan. Karena itu, maka sektor pariwisata merupakan salah satu sektor yang mampu 
mengintegrasikan kemajuan perekonomian pada berbagai dimensi pada skala nasional, regional, dan global. Adapun kemiskinan merupakan permasalahan nasional, regional dan global yang selalu harus ditangani secara serius. Mengentaskan kemiskinan memerlukan dana besar. Salah satu cara mengentaskan kemiskinan rakyat adalah melibatkan rakyat miskin dalam berbagai kegiatan yang integratif dengan bisnis pariwisata.

\section{B. METODE PENELITIAN}

Penelitian ini merupakan penelitian kualitatif dengan pendekatan yang digunakan berdasarkan studi literature dengan cara mencari teori yang relevan dengan permasalahan yang ditemukan. Adapun literature yang digunakan berkaitan dengan jumlah kunjungan wisatawan ke Jawa Timur.

\section{HASIL DAN PEMBAHASAN}

Hal menarik yang perlu disampaikan bahwa secara awam sektor pariwisata telah menjadi andalan perkembangan ekonomi di berbagai kota atau kabupaten namun kata pariwisata tidak dapat ditemukan dalam klasifikasi baku jenis lapangan usaha di Indonesia yang dituangkan dalam Peraturan Kepala Badan Pusat Statistik nomor 57 tahun 2009 tentang klasifikasi baku lapangan usaha Indonesia. Jenis lapangan usaha yang paling dekat hubungannya dengan pariwisata adalah poin ke delapan belas tentang Kebudayaan, Hiburan dan Rekreasi. Hal ini selaras dengan apa yang ada di International Standard Industrial Classification of All Economic Activities (ISIC), Revision 4, Complete structure draft for discussion, yang diterbitkan pada tanggal 12 Mei 2004 [4]. Sehingga tatkala memperhatikan produk domistik bruto (PDRB) sebuah kabupaten atau kota juga tidak didapatkan sektor pariwisata. Namun, dalam Buku Berita Resmi Statistik dari Badan Pusat Statistik disebutkan perkembangan sektor pariwisata terkait kunjungan wisatawan juga dalam Buku Berita Resmi Statistik dari Badan Pusat Statistik Jawa Timur yang melaporkan tentang jumlah kunjungan dan asal negara wisatawan mancanegara yang berkunjung ke Jawa Timur dan tingkat penghunian kamar (TPK) hotel berbintang di Jawa Timur.

Buku Berita Resmi Statistik dari Badan Pusat Statistik no. 35/04/th. xviii, 1 april 2015 tentang perkembangan pariwisata dan transportasi nasional februari 2015 disampaikan bahwa jumlah kunjungan wisatawan mancanegara (wisman) ke Indonesia pada Februari 2015 mencapai 786,7 ribu kunjungan atau naik 11,95 persen dibandingkan jumlah kunjungan wisman Februari 2014, yang tercatat sebanyak 702,7 ribu kunjungan. Demikian pula jika dibandingkan dengan Januari 2015, jumlah kunjungan wisman Februari 2015 naik sebesar 8,80 persen. Secara kumulatif (Januari-Februari) 2015, jumlah kunjungan wisman mencapai 1,51 juta kunjungan atau naik 3,71 persen dibanding kunjungan wisman pada periode yang sama tahun sebelumnya, yang berjumlah 1,46 juta kunjungan. [2]

Sedangkan dalam Buku Berita Resmi Statistik dari Badan Pusat Statistik Jawa Timur No. 36/o6/35/Th.XIV, 1 Juni 2016 perkembangan Pariwisata Jawa Timur, April 2016. Selama bulan April 2016 jumlah wisman di Jawa Timur melalui pintu masuk Juanda naik sebesar 1,63 persen sedangkan TPK hotel berbintang naik sebesar 5,75 poin. Jumlah wisatawan mancanegara (wisman) yang datang ke Jawa Timur melalui pintu masuk Juanda pada bulan April 2016 mencapai 18.186 kunjungan atau naik sebesar 1,63 persen dibanding jumlah wisman bulan Maret 2016 yang sebanyak 17.894 kunjungan. Secara kumulatif, jumlah wisman Januari - April 2016 mencapai 62.709 kunjungan atau naik sebesar 1,52 persen dibanding jumlah wisman periode yang sama tahun 2015 yang mencapai 61.770 kunjungan. Pada bulan April 2016 wisman terbanyak berkebangsaan Malaysia, jumlahnya mencapai 4.807 kunjungan atau naik 10,35 persen, diikuti kebangsaan Singapura 1.654 kunjungan atau turun sebesar 24,51 persen, dan kebangsaan Tiongkok sebanyak 1.369 kunjungan atau turun sebesar 2,84 persen dibanding bulan Maret 2016. penjelasan data tersebut menunjukkan bahwa pariwisata merupakan suatu system yang didalamnya terdapat sektor-sektor terkait yang mendukung keberadaannya.

Sebelum membahas peranan pariwisata dalam mengentaskan kemiskinan penting untuk disampaikan tentang pembangunan berkelanjutan. Kesadaran terhadap pembangunan berkelanjutan diawali dari konferensi PBB tentang Pembangunan Berkelanjutan pada 2012 di Rio de Janeiro merupakan seperangkat tujuan yang dapat diwujudkan secara global dengan memadukan dan menyeimbangkan tiga dimensi pembangunan berkelanjutan yaitu lingkungan hidup, social dan ekonomi. (UNDP, 2012). Satu bumi dengan batasan geografis yang sebenarnya sangat tegas namun selalu berusaha untuk dilanggar dengan harapan mendapatkan tambahan ruang untuk hidup manusia. Keseimbangan bumi menjadi terancam, semakin menguat kesadaran bahwa upaya rekayasa dengan meminimkan peran alam akan menimbulkan dampak ikutan yang cenderung negatif dengan tingkat penanganan yang lebih tinggi. Kota layak huni yang sehat tergantung pada lingkungan yang sehat, ekonomi yang kuat dan penciptaan lapangan kerja yang cukup. Kota yang berkelanjutan adalah salah satu yang mampu menyediakan kebutuhan dasar penduduk dengan infrastruktur yang diperlukan yaitu fasilitas sipil, kesehatan dan perawatan medis, perumahan, pendidikan, transportasi, pekerjaan dan tata pemerintahan yang baik untuk semua lapisan 
masyarakat tanpa diskriminasi. Empat komponen dari Livability yaitu: (A) Kesejahteraan Sosial (B) Vitality Ekonomi (C) Ketersediaan Infrastruktur (D) Kualitas Lingkungan yang baik. Harus ada keseimbangan antara 4 komponen tersebut dan harus dipantau secara teratur. Pembangunan berkelanjutan lebih mengacu pada proses daripada titik akhir.

Dimasa depan, perlu adanya reorientasi paradigma dimana kota merupakan entity kawasan atau wilayah, yang berarti kota bukan saja sebagai "Engine of National \& Regional Growth" tetapi sekaligus "Kota yang Nyaman/Layak Huni, Berkelanjutan dan Berkeadilan". Dengan demikian, arah kebijakan pembangunan perkotaan dimasa depan harus memenuhi fungsi entity kawasan/wilayah tersebut, yang dapat dideskripsikan secara detil sebagai berikut:

- Nyaman/layak huni (livable)

Memenuhi kebutuhan manusia akan kenyamanan hidup, fisik, sosial budaya, dan lingkungan.

- Berkelanjutan (sustainable)

Antisipasi terhadap perubahan iklim dan bencana alam serta memenuhi keperluan hidup manusia saat ini dengan tanpa mengabaikan keperluan hidup manusia masa datang

- Berkeadilan (just)

Menyediakan ruang hidup dan berusaha bagi seluruh golongan masyarakat perkotaan

- Pendorong pertumbuhan (engine of growth)

Mampu berkompetisi dalam perkembangan ekonomi global dengan memanfaatkan potensi sosial budaya dan kreatifitas lokal (ekonomi kreatif); serta mampu menciptakan hierarki pasar ba-gi kota menengah, kecil, dan perdesaan.

Secara definisi, pembangunan berkelanjutan adalah pembangunan untuk memenuhi keperluan hidup manusia kini dengan tanpa mengabaikan keperluan hidup manusia masa datang (Brundlandt, 2001). Bila dikaitkan dengan lingkungan maka pembangunan berkelanjutan dapat juga didefinisikan sebagai kemajuan yang dihasilkan dari interaksi aspek lingkungan hidup, dimensi ekonomi dan aspek sosial politik sedemikian rupa, masing-masing terhadap pola perubahan yang terjadi pada kegiatan manusia dapat menjamin kehidupan manusia yang hidup pada masa kini dan masa mendatang dan disertai akses pembangunan sosial ekonomi tanpa melampaui batas ambang lingkungan (WCED, 1987).

Pembangunan kepariwisataan yang berkelanjutan, adalah pembangunan yang menjamin bahwa keuntungan yang optimal akan diperoleh secara berkelanjutan, hanya dapat diwujudkan dengan pendekatan (kebijakan) yang bersifat komprehensip dan terintegrasi. Pembangunan kepariwisataan harus menganut prinsip di sini senang, di sana senang. Artinya, prinsip tersebut harus dapat menyebabkan wisatawan kembali ke rumah dengan membawa memori yang indah tentang destinasi pariwisata atau daya tarik wisata karena telah memberikan kenangan manis untuk wisatawan dan mengajarkan sesuatu yang berharga bagi wisatawan (selain memperoleh keuntungan ekonomi). Suatu pantangan dalam pengembangan pariwisata adalah wisatawan merasa jera yang berakibat keengganan wisatawan untuk kembali. Timbulnya rasa jera paling sering disebabkan oleh ketidakjujuran pengelola termasuk masyarakat dilokasi pariwisata. Sejelek apapun kondisi infrastruktur jika disampaikan sejak awal dengan jujur tidak akan berdampak pada rasa senang atau puas, hal ini terutama untuk wisatawan dari negara maju. Mereka lebih siap dengan segala kondisi asalkan sudah disampaikan diawal. Misalnya kondisi tidak ada penginapan atau jembatan yang terputus dan kemudian diganti dengan jembatan darurat malah akan jadi atraksi tersendiri bagi mereka. Kondisinya akan bertolak belakang jika tidak jujur dalam menyampaikan kondisi objek wisata, meski infrastruktur pendukungnya sudah lengkap dan bagus. Semisal, harga yang sebenarnya dinaikkan secara sepihak beberapa kali, mungkin dari sisi nilai uangnya tidak seberapa tapi hal semacam ini akan menjadikan mereka jera dan akan berakibat fatal pada keberlanjutan pengembangan kawasan wisata yang dimaksud. Promosi dari mulut kemulut karena merasa senang dan puas akan lebih berhasil secara efektif, sebaliknya penyampaian hal negative karena faktor jera akan sangat cepat meluas dan sulit untuk menumbuhkan kepercayaan ulang.

Pemanfaatan potensi sumber daya alam sering tidak dilakukan secara optimal dan cenderung eksploitatif. Kecenderungan ini perlu segera dibenahi salah satunya melalui pengembangan industri pariwisata dengan menata kembali berbagai potensi dan kekayaan alam dan budaya berbasis pada pengembangan kawasan secara terpadu. Potensi wisata alam dan budaya berbasis pada pengembangan kawasan secara terpadu.

Potensi wisata alam dan budaya pada satu kawasan dikembangkan dalam upaya mensinergikan berbagai kepentingan sebagaimana makna dari suatu kawasan merupakan keterpaduan penegelolaan yang memiliki nilai promosi yaitu one stop service, intinya pada suatu tempat dapat diberikan pelayanan dari berbagai jasa usaha pariwisata dan dapat menikmati berbagai sajian terpadu untuk tercapainya optimalisasi aset kepariwisataan dan kebudayaan sebagai langkah pemberdayaan masyarakat, menuju kepada pendekatan penting Comunity Based Tourism 
dan Comunit Based Culture Centered. Pariwisata dan kemiskinan secara langsung maupun tidak langsung mempunyai keterkaitan khususnya masyarakat yang menggantungkan pendapatan melalui pariwisata. Pengembangan pariwisata tentunya memiliki dampak positif dan negative, yaitu:

Dampak Positif :

1. Membuka lapangan kerja bagi penduduk lokal di bidang pariwisata seperti : tour guide, waiter, bell boy, dan lain-lain.

2. Dibangunnya fasilitas dan infrastruktur yang lebih baik demi kenyamanan para wisatawan yang juga secara langsung dan tidak langsung bisa dipergunakan oleh penduduk lokal pula. Seperti : tempat rekreasi, mall, dan lain-lain.

3. Mendapatkan devisa (national balance payment) melalui pertukaran mata uang asing (foreign exchange).

Dampak Negatif :

1. Bahaya ketergantungan yang sangat mendalam terhadap pariwisata.

2. Meningkatkan inflasi dan harga jual tanah menjadi mahal.

3. Meningkatkan impor barang dari luar negri, terutama alat-alat teknologi modern yang digunakan untuk memberikan pelayanan bermutu pada wisatawan dan juga biaya-biaya pemeliharaan fasilitas-fasilitas yang ada.

Pelibatan masyarakat (terutama disekitar lokasi tujuan wisata) secara utuh dan menyeluruh dari awal perencanaan hingga pelaksanaan pembangunan akan memberikan dampak yang sangat positif terutama peningkatan kesadaran wisata pada tataran masyarakat. Masyarakat sadar wisata merupakan tulang punggung dan ujung tombak pengembangan pariwisata berbasis masayarakat. Kesadaran masyarakat terhadap prinsip-prinsip pariwisata akan menghindarkan kejadian wisatawan merasa jera, sehingga kepuasan yang didapat oleh wisatawan. Dikaitkan dengan pemanfaatan sektor pariwisata dalam mendukung upaya pengetasan kemiskinan (poverty alleviation), perlu dipahami bahwa hal tersebut tidak boleh diartikan sebagai secara sengaja menempatkan pelaku dalam industri pariwisatakhususnya tenaga kerja dan pengusaha kecil dan menengah sebagai pihak yang perlu dikasihani, sehingga bisnis pariwisata menjadi sebuah bisnis berdasarkan " belas kasihan". Profesionalisme mereka harus ditingkatkan secara berkelanjutan, yang pada akhirnya akan meningkatkan kualitas pelayanan jasa dan kemudian mendorong peningkatan pendapatan.

Salah satu upaya penanggulangan kemiskinan adalah dengan memutus mata ratai kemiskinan melalui pemberdayaan kelompok masyarakat. Dalam mencapai tujuan pemberdayaan, berbagai upaya dapat dilakukan melalui berbagai macam strategi. Salah satu strategi yang memungkinkan adalah pengembangan pariwisata berbasis masyarakat yang secara konseptual memeliki ciri-ciri unik serta sejumlah karakter yang oleh Nasikun (2000:26-27) dikemukakan sebagai berikut:

1) Pariwisata berbasis masyarakat menemukakan rasionalitsnya dalam properti dan ciri-ciri unik dan karekter yang lebih unik diorganisasi dalam skala kecil, jenis pariwisata ini pada dasarnya merupakan, secara ekologis aman, dan tidak banyak menimbulkan dampak negatif seperti yang dihasilkan oleh jenis wisata konvensional,

2) Pariwisata berbasis komunitas memiliki peluang lebih mampu mengembangkan obyek-obyek dan atraksi-atraksi wisata berskala kecil dan oleh karena itu dapat dikelola oleh komunitaskomunitas dan pengusaha-pengusaha lokal,

3) Berkaitan sangat erat dan sebagai konsekuensi dari keduanya lebih dari pariwisata konvesional, dimana komunitas lokal melibatkan diri dalam menikmati keuntungan perkembangan pariwisata, dan oleh karena itu lebih memberdayakan masyarakat.

\section{SIMPULAN DAN SARAN}

Berdasarkan pembahasan berkaitan dengan pariwisata, pengentasan kemiskinan dapat disimpulkan:

a. Pariwisata merupakan suatu sistem yang dapat menjadi sektor andalan perekonomian dalam menciptakan lapangan pekerjaan dan pengetasan kemiskinan.

b. Pembangunan pariwisata berkelanjutan membutuhkan keterlibatan masyarakat secara menyeluruh dari keseluruhan tahapan pembangunan, dari tahap perencanaan hingga pelaksanaan pembangunan sehingga masyarakat punya kesadaran yang tinggi terhadap pengawasan dan pemeliharaan hasil pembangunan pariwisata.

c. Peningkatan Sumber Daya Manusia (SDM) berkaitan dengan pariwisata sangat dibutuhkan dalam meningkatkan kesadaran wisata bagi masyarakat yang berkonsekuensi pada kesejahteraan dan pelayanan optimal yang akan berdampak pada peningkatan pendapatan masyarakat.

d. Mengatasi masalah kemiskinan adalah dengan memberdayakan manusia agar dapat lebih aktif sehingga dapat terlepas dari belenggu kemiskinan

e. Penghapusan kemiskinan membutuhkan usaha bersama, pemerintah, organisasi masyarakat, sektor swasta, dalam konteks kemitraan global untuk pembangunan lebih kuat dan lebih efektif melalui upaya-upaya mencapai cita-cita secara sistemik. 


\section{E. REFERENSI}

[1] Bahan kuliah, Sustainable Urban Development Future of Indian Cities : An overview.

[2] Badan Pusat Statistik. Buku Berita Resmi Statistik no. 35/o4/th. XVIII, Jakarta, 2015

[3] I Wayan Suweda, Penataan Ruang Perkotaan Yang Berkelanjutan, Berdaya Saing Dan Berotonomi (Suatu Tinjauan Pustaka), Jurnal Ilmiah Teknik Sipil Vol. 15, No. 2, Fakultas Teknik Universitas Udayana, Denpasar, Juli 2011
[4] International Standard Industrial Classification of All Economic Activities (ISIC), Revision 4, Complete structure draft for discussion, diterbitkan pada tanggal 12 Mei 2004

[5] Soekadijo,R.G., Anatomi Pariwisata, Gremedia Pustaka Utama, Jakarta, 2000.

[6] Yoeti, Oka H.A. (ed), Ilmu Pariwisata: Sejarah Perkembangan, dan Prospeknya, Penerbit Pertja, Jakarta, 